sciendo

\title{
THE RIGHT, PROCEDURES AND REASONS OF THE WITHDRAWAL OF STATES FROM INTERNATIONAL ORGANIZATIONS
}

\author{
Viona Rashica \\ PhD Candidate of Political Sciences, South East European University, Tetovo, North Macedonia \\ vr26813@seeu.edu.mk
}

\begin{abstract}
Withdrawal is an act by which a member state of an international organization willingly terminates its membership. The right to withdraw from international organizations is explicitly mentioned in the constitutions of most of them and the circumstances regarding to the right of withdrawal vary depending on the organization. The purpose of this paper is to explain the right and procedures of withdrawal, and the reasons that result with the will of states to withdraw from international organizations. For the realization of this research are used qualitative methods, based on the bibliography that is related to international organizations, with special emphasis with the right and procedures of the withdrawal of states from international organizations. Furthermore, some informations are also collected from the credible internet sources, which have valuable data about the withdrawals of states from international organizations and the reasons that result with such decisions. The results of the research have shown that since the appearance of international organizations until today, there were and there are decisions of states to withdraw from international organizations, coming from the reluctance of states to hand over to international organizations parts of their sovereignty. The conclusions of this paper aim to increase knowledge about the real meaning of the processes of withdrawals of states from international organizations.
\end{abstract}

$\underline{\text { Key words: }}$ states, international organizations, withdrawal, processes. 


\section{INTRODUCTION}

The paper treats one topic which is about a very important part of international relations, the termination of the membership of states in international organizations through withdrawal. The latter one presents a very serious challenge for states and international organizations, because withdrawal is a process that is accompanied with hard consequences. The main research purposes of the paper are these: To explain the main characteristics of international organizations, to clarify the definition of the withdrawal of states from international organizations and to describe different examples of the withdrawal of states from certain organizations, that have an important role in the international arena. The research question of the paper is: What compels states to withdraw from international organizations? While the hypothesis of this paper is: Hesitations to hand over parts of sovereignty of states to international organizations result with decisions for withdrawal.

Therefore, to give the research question the right answer and to identify the raised hypothesis, the paper is divided into three chapters. The first chapter explains the main characteristics of international organizations, including their appearance, role and categorization. The second chapter clarifies the definition of withdrawal of states from international organizations, while the third chapter describe some examples of the withdrawals of states from international organizations like the League of Nations, the UN, the World Bank, the IMF, the OIC, the NATO, the Council of Europe, the EU and the OAS. This paper has an explanatory, descriptive, analytical and comparative nature, and for its realization are used qualitative methods, relying in the latest literature and the credible internet sources that are related to international organizations, especially to the withdrawal of states from international organizations.

\section{THE MAIN CHARACTERISTICS OF INTERNATIONAL ORGANIZATIONS THE APPEARANCE OF INTERNATIONAL ORGANIZATIONS}

Bilateral and multilateral relations between states have a long history, but the establishment of public international organizations functioning as institutions is essentially a development of the late nineteenth century. The nineteenth century has been described as "the era of preparation for international organization", this chronological period being between 1815 and 1914, while the years which have passed since the momentous events of 1914 must in a sense be regarded as "the era of establishment of international organization, which, in these terms comes to be regarded as a phenomenon of the twentieth century". International organization means an organization established by treaty or other instrument governed by international law and 
possessing its own international legal personality. International organizations may include as members, in addition to states, other entities (Crawford, 2012, p. 779). The Peace of Westphalia in 1648, the Congress of Vienna in 1815, the Congress of Berlin in 1871, the Hague Conferences in 1899 and 1907, and the Treaty of Versailles in 1919 were international conferences that preceded the establishment of international organizations. It was in 1919 during the aftermath of the tragedy and suffering caused by World War I and after the Treaty of Versailles, when the League of Nations was created in 1920, as an attempt to create a political organization of an open and universal character (Amerasinghe, 2005, p. 1-5). The League of Nations was an absolute novelty in the history of international relations. An organization on such a scale, covering all fields of international cooperation, never existed before (Ginneken, 2006, p. 37). This organization was designed "to promote international cooperation and to achieve peace and security" based on open, just, and honorable relations between nations (Herren, 2014, p. 16). By the late 1930s, the League was discredited as an instrument of collective security and its demise was rapid. After the outbreak of World War II in September 1939, the League's operations in Geneva were suspended. The League continued to exist in the United States and Canada but without a significant role in international relations. Plans began to be made toward the end of the war for a new, stronger international organization to replace it, this was the United Nations in 1945. The members of the League gathered for a final meeting in April 1946 at which they voted the organization out of existence (Lamb \& Snape, 2017, p. 214).

\section{THE ROLE OF INTERNATIONAL ORGANIZATIONS}

The number of international organizations has an extraordinary increase, especially after the Second World War until today. Analysts of international organizations have pointed to many precursors of contemporary institutions, like the UN, the WTO or the EU, that have played an increasingly significant part in the shaping of the modern world order (Armstrong, Lloyd \& Redmond, 2004, p. 1). In recent years, political science has often assessed the increasing influence of international organizations on national policy-making, most often under the title of "global governance." In many policy fields, international organizations have developed activities that shape the national perception and treatment of political, economic and other issues. In such processes, methodological nationalism - the search for explanations within the nation-state as the decisive entity - is challenged. The nation can no longer be presumed to be the dominant organizing principle of politics. Instead, conditions on the international level and the interdependence of countries become increasingly relevant (Jakobi, 2009, p. 50). It can be 
argued that the key global power shift is not from the West to the East but from the state to international organizations and other non-state actors (Lamb \& Snape, 2017, p. 182-183).

\section{THE CATEGORIZATION OF INTERNATIONAL ORGANIZATIONS}

There are various elements regarding the categorization of international organizations. We distinguish transnational voluntary organizations initiated by (sometimes state-owned) companies with a large mandate for experts, or created by experts themselves, from treatybased international organizations with a greater formal role for governments (Kaiser \& Schot, 2014 , p. 295). Therefore, the main categorization of international organizations is that are divided into international governmental organizations in which states operate on the basis of international treaties, and international non-governmental organizations which form a wide circle of groups and individuals from different countries of the world (Vukadinoviç, 2009, p. 127). An important component of the categorization of international organizations is geographical scope, based on which international organizations are divided into universal as the UN and its specialized agencies, or regional as the European Union or the African Union. There are also various different ways of categorizing international organizations. It can be done by purpose, some organizations have a specific purpose, the regulation of international whaling, for example, in the case of the International Whaling Commission, health in the case of the World Health Organization, monetary and financial stability in the case of International Monetary Fund, or collective defense in the case of the North Atlantic Treaty Organization. Alternatively, organizations can have a more general purpose, such as the UN, World Trade Organization, or the Organisation of Islamic Cooperation. They can also be categorized by membership, in particular whether it is universal in the case of the World Bank or limited. Membership might be limited to states in a particular geographical region, such as the Organization of American States and the Association of Southeast Asian Nations, by religion, such as the Organization of Islamic Cooperation, or by history. The Commonwealth, for example, is a collection of fairly disparate states, the majority of whom share a history of British colonialism (Lamb\&Snape, 2017,p. 182). 


\section{THE DEFINITION OF THE WITHDRAWAL OF STATES FROM INTERNATIONAL ORGANIZATIONS}

\section{THE RIGHT AND CONDITIONS OF WITHDRAWAL}

Termination of membership may clearly take place when an organization is dissolved. But, while the organization continues to exist, membership may be terminated by withdrawal (a voluntary act of the member state), by expulsion (a measure taken by the organization against the member state) and by the loss of membership upon failure to accept an amendment of the constitution of the organization. Another reason for termination not often mentioned is the disappearance of the member state or loss of its essential characteristics as a state. The right to withdraw is expressly referred in the constitutions of most of international organizations and the conditions attached to the right of withdrawal vary. Some organizations impose clear limitations on withdrawal, in some cases it is not permitted during an initial period, so as to allow the organization time to become established. Whereas, in some cases a period is prescribed between the giving of notice to withdraw and the coming into effect of withdrawal, a kind of 'cooling-off' period to allow for reconsideration and other possibilities. Another condition sometimes attached to withdrawal is that outstanding obligations must be fulfilled before withdrawal is effective. In general the obligations specified are simply the financial obligations incurred as part of the budgetary commitment, but in some cases the fulfilment of obligations other than financial ones is required. It should be emphasized that when an organization finances itself, as is the case with the financial organizations, the settlement of accounts with a withdrawing member is even more complicated. Policy considerations favouring the view that withdrawal is permissible even in the absence of express provision have been based on the concepts of sovereignty and self-determination, equity, expediency and general principles of law. There is a question whether a member state can suspend its notice, once given. The answer should be that it cannot, unless the rest of the members agree (Amerasinghe, 2005, p. 119-120).

\section{THE ABSENCE OF WITHDRAWAL CLAUSE}

The difficult question is what happens in the absence of a withdrawal clause. Some have argued that in such a situation member states have no right of unilateral withdrawal, this view being sometimes expressed as a consequence of the applicability of Articles 54 to 56 of the Vienna 
Convention on the Law of Treaties ${ }^{1}$ to constitutions of international organizations as to any other treaty. The Article 54 states that the termination of a treaty or the withdrawal of a party may take place:

1. In conformity with the provisions of the treaty;

2. At any time by consent of all the parties after consultation with the other contracting States.

The Article 55 is about reduction of the parties to a multilateral treaty below the number necessary for its entry into force which highlights that: Unless the treaty otherwise provides, a multilateral treaty does not terminate by reason only of the fact that the number of the parties falls below the number necessary for its entry into force ("Vienna Convention on the law of treaties (with annex). Concluded at Vienna on 23 May 1969," 1980).

Denunciation of or withdrawal from a treaty containing no provision regarding termination, denunciation or withdrawal is emphasized on the Article 56 that states:

1. A treaty which contains no provision regarding its termination and which does not provide for denunciation or withdrawal is not subject to denunciation or withdrawal unless:

a. It is established that the parties intended to admit the possibility of denunciation or withdrawal;

b. A right of denunciation or withdrawal may be implied by the nature of the treaty.

2. A party shall give not less than twelve months' notice of its intention to denounce or withdraw from a treaty under paragraph 1 (Dörr \& Schmalenbach, 2018, p. 1039).

Article 56, which applies to both bilateral and multilateral treaties, distinguishes between three terms: the termination of a treaty, the denunciation of a treaty and the withdrawal from a treaty.

\footnotetext{
${ }^{1}$ The Vienna Convention on the Law of Treaties is an international agreement regulating treaties between states, that is signed on 23 May 1969 in Vienna and entered into force on 27 January 1980. Known as the "treaty on treaties", it establishes the rules and procedures for how treaties are defined, drafted, enforced, amended, interpreted, and generally operate.
} 


\section{EXAMPLES OF THE WITHDRA WALS OF STATES FROM INTERNATIONAL ORGANIZATIONS}

\section{WITHDRA WAL FROM THE LEAGUE OF NATIONS}

Withdrawal of member states from the League of Nations was stated on the Article 1 of its Covenant $^{2}$. This article stated that: Any Member of the League may, after two years' notice of its intention so to do, withdraw from the League, provided that all its international obligations and all its obligations under this Covenant shall have been fulfilled at the time of its withdrawal. ("The Covenant of the League of Nations," n.d.). From its establishment in 1920 to its dissolution in 1946, the League of Nations has had many cases of withdrawals of states. The first state to have withdrawn from the League was Costa Rica in December 1924, continuing with Brazil in June 1926, Japan in March 1933, Germany in October 1933, Paraguay in February 1935, Guatemala in May 1936, Nicaragua in June 1936, Honduras in July 1936, El Salvador in August 1937, Italy in December 1937, Chile in June 1938, Venezuela in July 1938, Peru in April 1939, Hungary in April 1939, Spain in May 1939, Romania in July 1940 and Haiti in April 1942 (Ginneken, 2006, p. 24-34). The withdrawals of these states were affected from the events before, during and after World War II.

\section{WITHDRAWAL FROM THE UNITED NATIONS}

The Charter ${ }^{3}$ of the UN contains no express provision prohibiting, permitting, or regulating the question of withdrawal from the organization, and the organization has on only one occasion had to deal with this situation. The only case of withdrawal that can be cited is that of Indonesia in 1965, when this state announced and put into effect its intention to withdraw from the UN as a protest against the election of Malaysia as a non-permanent member of Security Council. Notice of withdrawal was given in a letter to the Secretary General. Although in his letter of reply, the Secretary left open the issue of the legality of Indonesia's conduct, the UN's acquiescence to the withdrawal-defined as "inactive membership" can be inferred from a series of conclusive acts of the Organization, such as the cancellation of Indonesia from the list of members, the removal of the Indonesian flag and plate from the UN, its exclusion from the

\footnotetext{
${ }^{2}$ The Covenant of the League of Nations was the charter of the League of Nations that was signed on 28 June 1919 in Paris as Part I of the Treaty of Versailles, and became effective together with the rest of the Treaty on 10 January 1920.

${ }^{3}$ The Charter of the United Nations is the foundational treaty of the UN that was signed on 26 June 1945 in San Francisco, at the conclusion of the United Nations Conference on International Organization, and came into force on 24 October 1945.
} 
budget documents, and so on (Conforti \& Focarelli, 2016, p. 53). However, at the end of 1966, Indonesia informed the Secretary-General that Indonesia had decided to resume participation in its activities starting with the Twenty-First Session of the General Assembly. Because of its peculiar characteristics, and especially because of the rather tenuous and sui generis justification brought by Indonesia as grounds for withdrawal, this case seems to testify to the view that each member state has a complete and unconditional right to withdraw from the UN. According to the UN Handbook on the Final Clauses of Multilateral Treaties, the words denunciation and withdrawal express the same legal concept. Denunciation (or withdrawal) is a procedure initiated unilaterally by a state to terminate its legal engagements under a treaty (Cogan, Hurd \& Johnstone, 2016, p. 982-983). Nonetheless, two articles of the UN Charter should not be overlooked because they relate to the compulsory withdrawal, or to expulsion of states from the UN. Article 5 states that a Member of the United Nations against which preventive or enforcement action has been taken by the Security Council may be suspended from the exercise of the rights and privileges of membership by the General Assembly upon the recommendation of the Security Council. The exercise of these rights and privileges may be restored by the Security Council. Whereas Article 6 states that a Member of the United Nations which has persistently violated the Principles contained in the present Charter may be expelled from the Organization by the General Assembly upon the recommendation of the Security Council ("Chapter II: Membership," n.d.).

\section{WITHDRAWAL FROM THE WORLD BANK}

Withdrawal and Suspension of Membership from the World Bank is regulated on the Article 6 of the IBRD Articles of Agreement ${ }^{4}$. Based on this article, any member may withdraw from the Bank at any time by transmitting a notice in writing to the Bank at its principal office. Withdrawal shall become effective on the date such notice is received. Section 2 of the Article 6 states that if a member fails to fulfill any of its obligations to the Bank, the Bank may suspend its membership by decision of a majority of the Governors, exercising a majority of the total voting power. The member so suspended shall automatically cease to be a member one year from the date of its suspension unless a decision is taken by the same majority to restore the member to good standing. While under suspension, a member shall not be entitled to exercise

\footnotetext{
${ }^{4}$ The International Bank for Reconstruction and Development Articles of Agreement were drawn up at the United Nations Monetary and Financial Conference, at Bretton Woods, New Hampshire, on 1-22 July 1944. The governing document became effective on 27 December 1945, and has been amended three times: 17 December 1965, 16 February 1989 and 27 June 2012.
} 
any rights under this Agreement, except the right of withdrawal, but shall remain subject to all obligations ("Withdrawal and Suspension of Membership: Suspension of Operations," 2012).

\section{WITHDRA WAL FROM THE INTERNATIONAL MONETARY FUND}

A member may be withdrawn from the IMF because it is deemed to have withdrawn whether it in fact wishes to withdraw or not, or it may withdraw voluntarily, or it may be required to withdraw. Based on the Article 25 of the Articles of Agreement of the IMF ${ }^{5}$, any member may withdraw from the Fund at any time by transmitting a notice in writing to the Fund at its principal office. Withdrawal shall become effective on the date such notice is received ("Articles of Agreement of the International Monetary Fund - Article XXVI: Withdrawal from Membership," 2016). There were three cases of voluntary withdrawal from the IMF. Poland withdrew from IMF in March 1950 because according to the Polish government Fund had failed to fulfill its duties, had been a submissive instrument of the policy of the Government of the US, and had cooperated lately with the US in forcing a number of members to devalue their currencies. Cuba withdrew from the Fund in April 1964 because failed to fulfill its duties as an IMF member state. Indonesia for the same reasons that decided to withdrew from the UN, withdrew from IMF in August 1965 ("Membership and Non-Membership in the International Monetary Fund: Three Cases of Voluntary Withdrawal," 1985). Whereas, on the Section 2 of the aforementioned article is regulated compulsory withdrawal from the IMF if a member fails to fulfill any of its obligations under the Agreement of the IMF. There was such a case of compulsory withdrawal of Czechoslovakia from IMF in September 1954 ("The Compulsory Withdrawal of Czechoslovakia,” 1968).

\footnotetext{
${ }^{5}$ Articles of Agreement of the International Monetary Fund were adopted at the United Nations Monetary and Financial Conference, Bretton Woods, New Hampshire on 22 July 1944, entered into force on 27 December 1945, amended effective on 28 July 1969, amended effective on 1 April 1978 and amended effective on 11 November 1992.
} 


\section{WITHDRAWAL FROM THE ORGANIZATION OF ISLAMIC COOPERATION}

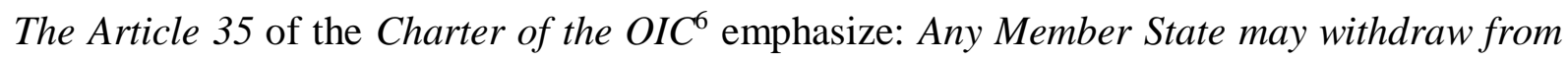
the Organisation by notifying the Secretary-General one year prior to its withdrawal. Such a notification shall be communicated to all Member States. The State applying for withdrawal shall be bound by its obligations until the end of the fiscal year during which the application for withdrawal is submitted. It shall also settle any other financial dues it owes to the Organisation (“OIC Charter: Withdrawal,"n.d.). There was a case of withdrawal of Zanzibar from OIC in August 1993. Tanzania is about 34\% Christian, 33\% Muslim and the 33\% other religions while Zanzibaris are mainly Muslim. The Zanzibar government said it joined the OIC in order to achieve greater economic benefits. Tanzanian President Mwinyi publicly endorsed the Zanzibar decision, but the opposition was incensed and demanded his impeachment and Zanzibar was later forced to withdraw from the OIC. The Government of Tanzania had strong reservations about Zanzibar's action as it believed that it was not in the best interests of the country to join an organisation representing only one of Tanzania's religions ("Chronology for Zanzibaris in Tanzania," 2004).

\section{WITHDRA WAL FROM THE NORTH ATLANTIC TREATY ORGANIZATION}

The withdrawal process of states from NATO is regulated by Article 13 of the North Atlantic Treaty $^{7}$. This article states: After the Treaty has been in force for twenty years, any Party may cease to be a Party one year after its notice of denunciation has been given to the Government of the United States of America, which will inform the Governments of the other Parties of the deposit of each notice of denunciation ("The North Atlantic Treaty: Article 13," 2019). There are some cases of contemplated withdrawal of states from NATO. In 1966, President Charles de Gaulle withdrew France from NATO's integrated military command structure (a decision that was reversed in 2009 by President Nicolas Sarkozy) ("France and NATO,” n.d.). In 1964,

\footnotetext{
${ }^{6}$ The first OIC Charter was adopted in 1972 and laid down the objectives and principles of the organization and fundamental purposes to strengthen the solidarity and cooperation among the member states. Over the last 40 years, the membership has grown from its founding members of 30 to 57 states. The Charter was amended to keep pace with the developments that have unraveled across the world. The present Charter of the OIC was adopted by the Eleventh Islamic Summit held in Dakar on 13-14 March 2008 to become the pillar of the OIC future Islamic action in line with the requirements of the 21 st century.

${ }^{7}$ The North Atlantic Treaty, also referred to as the Washington Treaty, is the treaty that forms the legal basis of, and is implemented by, the North Atlantic Treaty Organization. It was signed in Washington on 4 April 1949.
} 
Greece decided to withdraw certain army, navy and air force units from NATO to fulfill her commitments toward Cyprus, to support it against any Turkish attack ("Greece Withdrawing Units From NATO to Aid Cyprus," 1964), and in 1974, Greece withdrew from NATO military command (“Greece refuses to join in NATO Maneuvers," 1983).

\section{WITHDRAWAL FROM THE COUNCIL OF EUROPE}

The Article 7 of the Statute of the Council of Europe ${ }^{8}$ has regulated the withdrawal of states from the Council of Europe. According to this article: Any member of the Council of Europe may withdraw by formally notifying the Secretary General of its intention to do so. Such withdrawal shall take effect at the end of the financial year in which it is notified, if the notification is given during the first nine months of that financial year. If the notification is given in the last three months of the financial year, it shall take effect at the end of the next financial year ("Statute of the Council of Europe: Article 7," 1949). There was a case of the will of withdrawal from the Council of Europe with Greece. On 12 December 1969, the Government of Greece notified the Secretariat General of its decision to withdraw from the Council of Europe in accordance with Article 7 of the Statute of the Council. Noting that in application of Article 7 of the Statute of the Council of Europe, the notification of Greece's withdrawal would come into force at the end of 1970 ("Legal and Financial Consequences of the Withdrawal of Greece from the Council of Europe," 1970). The country was readmitted to the organisation in 1974 following the fall of the dictatorial regime.

\section{WITHDRAWAL FROM THE EUROPEAN UNION}

While it has always been generally assumed that the EU could be dissolved and individual withdrawals permitted by an agreement of all the member states, most publicists believed before the entry into force of the Treaty of Lisbon ${ }^{9}$ in 2009 that the European treaties in their Nice version did not permit unilateral withdrawals, in view of express provisions stating that these treaties were concluded for unlimited periods. (Dörr \& Schmalenbach, 2018, p. 1057). The Lisbon Treaty for the first time defined the possibility of voluntary withdrawal of a member state from the EU according to the Article 50 which states that: If a member state decides to

\footnotetext{
${ }^{8}$ The Statute of the Council of Europe, also known as the Treaty of London 1949, is a treaty that was signed on 5 May 1949 in London, UK, which created the Council of Europe.

${ }^{9}$ The Treaty of Lisbon, initially known as the Reform Treaty, is an international agreement that amends the two treaties which form the constitutional basis of the European Union. The Treaty of Lisbon was signed by the EU member states on 13 December 2007, and entered into force on 1 December 2009.
} 
leave the EU, initially notifies the European Council for its intention, then the EU negotiates and reaches an agreement with that state, setting out the arrangements for its withdrawal, taking account of the framework for its future relationship with the EU. This agreement shall be concluded on behalf of the EU by the EC, acting by a qualified majority, after obtaining the consent of the European Parliament. If no agreement is reached two years after the withdrawal notice, the EC in agreement with the member state unanimously decide to extend this period ("The Lisbon Treaty - Article 50," n.d.). Brexit is a term formed by the unification of the words "Britain" and "Exit", referring to the referendum held on 23 June 2016 in the United Kingdom (Shipman, 2016, p. 22), in which the British voted $51.9 \%$ with $48.1 \%$ in favor of withdrawal from the EU ("EU referendum results", 2016). The British Government on 29 March 2017 confirmed to the EU its decision to activate the Article 50 ("Brexit: The UK's letter triggering Article 50", 2017) and the EC on 22 May 2017 approved the authorization decision to open Brexit negotiations, the commission and negotiating directives ["General Affairs Council (Art. 50), 22/05/2017", 2017]. The European Council has adopted a decision to extend the period under Article 50, in the context of the UK's intention to withdraw from the EU. This is a third extension of Brexit that will last until 31 January 2020 to allow more time for the ratification of the withdrawal agreement ("Brexit: European Council adopts decision to extend the period under Article 50," 2019).

\section{WITHDRAWAL FROM THE ORGANIZATION OF AMERICAN STATES}

The Article 143 of the Charter of the OAS ${ }^{10}$ emphasizes: The present Charter shall remain in force indefinitely, but may be denounced by any Member State upon written notification to the General Secretariat, which shall communicate to all the others each notice of denunciation received. After two years from the date on which the General Secretariat receives a notice of denunciation, the present Charter shall cease to be in force with respect to the denouncing State, which shall cease to belong to the Organization after it has fulfilled the obligations arising from the present Charter ("Charter of the Organization of American states," n.d.). In April 2017, the Bolivarian Republic of Venezuela officially began the process of withdrawal from the OAS in a decision that President Nicolás Maduro affirmed on that occasion, "conforms sovereignly to the historical postulates of our Bolivarian independence process". The

\footnotetext{
${ }^{10}$ The Charter of the Organization of the American States is a Pan-American treaty that sets out the creation of the Organization of American States. It was signed at the Ninth International Conference of American States of 30 April 1948, held in Bogotá, Colombia and the treaty came into effect on 13 December 1951.
} 
Venezuelan leader said then - in an official letter - that the history of the Organization, both, before as for now, "expresses pitifully a corporation kidnapped from birth by interests contrary to the spirit of integration and union". Before the decision was adopted, extremist sectors of the local opposition encouraged an escalation of unprecedented violence in the country. The OAS, for its part, intensified the intervention in Venezuela's internal affairs in flagrant violation of the Organization's Charter, prompting the historic decision of the national Executive. On April 27, 2017, the Venezuelan diplomatic representation before the OAS delivered the letter signed by President Nicolás Maduro formalizing the withdrawal of the country from this organization. President Maduro had repeatedly pointed out that the OAS is a "flawed organism" and represented the interests "of imperialism and its way of doing criminal policy in the region" ("Venezuela ceases membership in the OAS this Saturday: What motivates this sovereign decision?," 2019). Officially Venezuela withdrew from OAS in April 2019.

\section{CONCLUSION}

The 21st century is characterized by the crisis of 3Es - Economics, Energy and Ecology. This explains that states are increasingly becoming interdependent on economic, energy and ecological plans, which also challenge international security. International organizations of each category are an important part of the efforts to solve such problems. However, international organizations are extremely challenging the states as the decisive entities. Some states that hesitate to transfer parts of their sovereignty within international organizations, choose the option of withdrawal, which means a voluntary act of the member state to leave its membership in organization. The right to withdraw is expressly referred on the treaties of most of international organizations and the conditions attached to the right of withdrawal vary. In general, the specified obligations of states that decide to withdraw are mostly the financial ones. Some international organizations have emphasized on their statutes the procedures which must follow states that decide to withdraw, whereas some organizations only the reasons of the expulsion of states. While the article that regulated the withdrawal of states was part of the Covenant of the League of Nations, the Charter of the UN does not have an article by which should be regulated the withdrawal of its member states. International organizations such as the IMF, the OIC, the NATO, the Council of Europe, the EU, the OAS etc., were faced or are facing with decisions of their member states to withdraw. With the exception of the League of Nations, a considerable part of the withdrawals of states from international organizations were made during the Cold War, a period characterized by various ideological clashes. Nevertheless, the 21 st century is facing with serious threats of some of the most important states in the world 
with big political and economic importance, to withdraw from international organizations, whether universal or regional, that have a major role in the international arena. The UK's decision to withdraw from the EU, known as the "Brexit", presents one of the most complicated cases of the withdrawal of a state by any international organization in this century. The complexity of Brexit stems from the fact that its consequences will not only affect the UK and the EU, but the whole world. The EU is not an international organization with universal character, but it is the biggest player on the global trade scene, while the UK has a very big political, economic and military role in the world. Withdrawals and threats of states to withdraw from international organizations prove that even in this century, the power of nationalism should not be underestimated, and the power of international organizations should not be overestimated, despite the fact that interdependence between states is increasing. 


\section{BIBLIOGRAPHY}

- Amerasinghe, F., C. (2005). Principles of the Institutional Law of International Organizations. 2nd ed. UK: Cambridge University Press.

- Armstrong, D., Lloyd, L. \& Redmond, J. International Organisation in World Politics. 3d ed. UK: Palgrave Macmillan.

- Cogan, K., J., Hurd, I. \& Johnstone, I., ed. (2016). The Oxford Handbook of International Organizations. UK: Oxford University Press.

- Conforti, B. \& Focarelli, C. (2016). The Law and Practice of the United Nations. 5th ed. The Netherlands: Brill.

- Crawford, R., J. (2012). Brownlie's Principles of Public International Law. 8th ed. UK: Oxford University Press.

- Dörr, O. \& Schmalenbach, K., ed. (2018). Vienna Convention on the Law of Treaties: A Commentary. 2nd ed. Berlin: Springer.

- Ginneken, M., H., A. (2006). Historical Dictionaries of International Organizations. USA: Scarecrow Press, Inc.

- Herren, M., ed. (2014). Networking the International System: Global Histories of International Organizations. USA: Springer.

- Jakobi, P., A. (2009). International Organizations and Lifelong Learning: From Global Agendas to Policy Diffusion. UK: Palgrave Macmillan.

- Kaiser, W. \& Schot, J. (2014). Writing the Rules for Europe: Experts, Cartels, and International Organizations. UK: Palgrave Macmillan.

- $\quad$ Lamb, P. \& Snape, R., F. (2017). Historical Dictionary of International Relations. UK: Rowman \& Littlefield.

- Shipman, T. (2016). All Out War: The Full Story of How Brexit Sank Britain's Political Class. UK: William Collins.

- Vukadinoviç, R. (2009). Marrëdhëniet Politike Ndërkombëtare. Prishtinë: Kolegji Victory.

\section{SOURCES FROM THE INTERNET}

- Articles of Agreement of the International Monetary Fund - Article XXVI: Withdrawal from Membership. (2016, January 26). Retrieved on October 10, 2019 from https://www.imf.org/external/pubs/ft/aa/pdf/aa.pdf.

- Brexit: European Council adopts decision to extend the period under Article 50. (2019, October 29). Retrieved on October 29, 2019 from https://www.consilium.europa.eu/en/press/pressreleases/2019/10/29/brexit-european-council-adopts-decision-to-extend-the-period-under-article$\underline{50 /}$.

- Brexit: The UK's letter triggering Article 50. Retrieved on October 3, 2019 from http://www.bbc.com/news/uk-politics-39431070.

- Charter of the Organization of American states. Retrieved on October 12, 2019 from http://www.oas.org/en/sla/dil/inter american treaties A-41 charter OAS.asp.

- Charter of the United Nations - Chapter II: Membership. Retrieved on October 10, 2019 from https://www.un.org/en/sections/un-charter/chapter-ii/index.html. 
- Chronology for Zanzibaris in Tanzania. (2004). Retrieved on October 12, 2019 from https://www.refworld.org/docid/469f38e61e.html.

- EU referendum results. Retrieved on October 3, 2019 from https://www.electoralcommission.org.uk/_data/assets/pdf_file/0008/215279/2016-EUreferendum-report.pdf.

- France and NATO. Retrieved on October 11, 2019 from https://www.nato.int/cps/en/natohq/declassified_160672.htm?selectedLocale=en.

- General Affairs Council (Art. 50), 22/05/2017. (2017, May 22). Retrieved on October 4, 2019 from http://www.consilium.europa.eu/en/meetings/gac-art50/2017/05/22/.

- Greece refuses to join in NATO Maneuvers. (1983, March 6). Retrieved on October 11, 2019 from https://www.nytimes.com/1983/03/06/world/greece-refuses-to-join-in-natomaneuvers.html.

- Greece Withdrawing Units From NATO to Aid Cyprus. (1964, August 18). Retrieved on October 11, 2019 from https://www.nytimes.com/1964/08/18/archives/greece-withdrawing-units-fromnato-to-aid-cyprus.html.

- Legal and Financial Consequences of the Withdrawal of Greece from the Council of Europe. (1970, November 27). Retrieved on October 13, 2019 from https://rm.coe.int/16804bc2a7.

- Membership and Non-membership in the International Monetary Fund: Three Cases of Voluntary Withdrawal. (1985, October). Retrieved on October 10, 2019 from https://asean.elibrary.imf.org/view/IMF071/15759-9781455215935/157599781455215935/ch16.xml.

- OIC Charter: Withdrawal. Retrieved on October 11, 2019 from https://www.oicoci.org/page/?p id=53\&p ref=27\&lan=en.

- Statute of the Council of Europe: Article 7. (1949, May 5). Retrieved on October 11, 2019 from https://rm.coe.int/1680306052.

- The Compulsory Withdrawal of Czechoslovakia. (1968, January). Retrieved on October 10, 2019 from https://www.elibrary.imf.org/view/IMF054/14812-9781451939118/148129781451939118/ch03.xml?rskey=a5gip9\&result $=4$.

- The Covenant of the League of Nations. Retrieved on October 10, 2019 from https://avalon.law.yale.edu/20th century/leagcov.asp.

- The Lisbon Treaty - Article 50. Retrieved on October 12, 2019 from http://www.lisbontreaty.org/wcm/the-lisbon-treaty/treaty-on-European-union-and-comments/title-6-finalprovisions/137-article-50.html.

- The North Atlantic Treaty: Article 13. (2019, April 10). Retrieved on October 10, 2019 from https://www.nato.int/cps/ie/natohq/official texts 17120.htm.

- Venezuela ceases membership in the OAS this Saturday: What motivates this sovereign decision?. (2019, April 26). Retrieved on October 13, 2019 from http://mppre.gob.ve/en/2019/04/26/venezuela-ceases-membership-oas-sovereign-decision/.

- Vienna Convention on the law of treaties (with annex). Concluded at Vienna on 23 May 1969. (1980, January 27). Retrieved on October 13, 2019 from https://treaties.un.org/doc/publication/unts/volume\%201155/volume-1155-i-18232-english.pdf.

- Withdrawal and Suspension of Membership: Suspension of Operations. (2012, June 27). Retrieved on October 10, 2019 from http://pubdocs.worldbank.org/en/722361541184234501/IBRDArticlesOfAgreement-English.pdf. 